\title{
Local participatory budgeting in a multilevel government - an institutional analysis of Ecuadorian municipal expenditure policies
}

\author{
Nils Droste ${ }^{1}$, Nele Lienhoop ${ }^{2}$, Bernd Hansjürgens ${ }^{3}$ \\ ${ }^{1}$ Lund University, Department of Political Science, Box 118, SE 22100 Lund, Sweden, nils.droste@,svet.lu.se, orcid: 0000-0003- \\ 4357-9115 \\ 2 Bochum University of Applied Sciences, Faculty of Economics, Lennershofstraße 140, 44801 Bochum, Germany, \\ nele.lienhoop@hs-bochum.de \\ ${ }^{3}$ UFZ - Helmholtz Centre for Environmental Research, Department of Economics, Permoserstr. 15, 04318 Leipzig, Germany, \\ bernd.hansjuergens@ufz.de orcid: 0000-0002-5650-8300
}

\begin{abstract}
This paper analyses participatory budgeting in multilevel governance settings. The Institutional Development and Analysis framework is applied to evaluate two Ecuadorian municipal case studies. Here, participatory budgeting piloted bottom-up institutions to include citizens' preferences in the allocation of local government expenditures. To formalize and up-scale these local innovations, participatory budgeting became a requirement for all government levels under the 2008 constitution. Higher government level requirements for planning subsequently introduced conflicting demands on decentral budgetary processes and led to partial re-centralization of municipal investment planning. The study thus exemplifies difficulties of i) vertical policy coordination in multilevel participatory budgeting and ii) integrating long-term planning in yearly participatory budgeting investment decisions. These problems need to be resolved to facilitate legitimate and effective participatory budgeting in multilevel governments.
\end{abstract}

Keywords: collective decision making, decentralization, institutional development, participatory governance

\section{Introduction}

2 Public spending policies could arguably aim at satisfying citizens' preferences for public goods.

3 Mechanisms that increase accountability and responsiveness in corresponding decision-making

4 processes are therefore not just subject to (normative) political and economic studies but also a 5 (practical) challenge for both policy makers and citizens (O'Flynn 2007). Many of such fiscal 6 mechanisms are formally defined in the constitutional division of competencies, expenditures and 7 revenues within multi-level government structures (Oates 1972). Goods and services of national 8 interest are arguably best provided through central government policies. Local municipal 9 government expenditures, however, provide access to many vital public goods and services for 10 their constituencies. Road infrastructure, potable water, sanitation, education, crime prevention, 
11 zoning, environmental protection and waste treatment are just of few of the goods and services that

12 can be found within the realm of municipal competencies and thus expenditure policies.

13 Optimistic theories promise that decentralization may serve to increase performance and 14 accountability of government behaviour (Rodden 2005; Faguet 2014; Tiebout 1956; Breton 1998).

15 The devolution of powers to lower level governments is often conceptualized as diminishing the distance between decision makers and citizens. It is argued that if decision makers are closer to the people, they will tend to make decisions that are in better alignment with preferences in their constituency (Oates 1999). Thus, regional variations in citizens' preferences can be better captured through decentral public policies (Oates 1972). There is empirical evidence to support such ideas from various contexts in both the industrialized and the developing world (Faguet 2004; Gonçalves 2014; Wright et al. 2015). While promising, decentralization is not a blueprint solution. It may be subject to captures by local elites and interest groups (Bardhan 2002). Opening up the decision making processes to public engagement may (Fung 2015) or may not (Hinnerich and PettersonLidbom 2014) balance out elite captures. Participatory mechanisms can enhance legitimacy and justice of bottom-up public policies but there is no guarantee. Allowing citizens to decide on public finance nevertheless integrates participation deep into the traditional authority of the executive: the power to spend public money. Correspondingly, the institutional design of participatory budgeting (PB) mechanisms and their potentially emancipatory power to align public finance with citizen preferences are of interest (Fung and Wright 2001; Fung 2006; Goldfrank and Schneider 2006). Yet, such a decentral, bottom-up participation may pose coordination problems of multi-level government cooperation, coordination, and vertical integration (Weingast 2014; De Mello 2000).

2 In this paper, we follow this line of inquiry and seek to answer: What can we learn from PB mechanisms about collective preference formulation in a multi-level government setting? To this end, we analyse PB mechanisms in Ecuador as municipalities in Ecuador have piloted PB since the early 2000's. Subsequently, the 2008 constitution established a nation-wide PB requirement for all 
government levels. The Ecuadorian case therefore serves as an example of a decentralized implementation within an overall constitutional framework. For the Ecuadorian case, our goals are twofold: (i) to study two municipal level PB mechanism and articulated preferences for public good provision from a comparative perspective, and (ii) elaborate on what we can learn about institutional development of a decentral PB in a multilevel government setting. We apply the institutional analysis and development framework (IAD) deductively to evaluate the general constitutional requirements in a multilevel government and the institutional development of two municipal PB case studies in Ecuador. We show that the two selected municipal PB case studies experimented with taking citizens preferences for public (infrastructure) development into account. The constitutional reform placed longer-term planning requirements on municipal governments that complicated local PB implementations of yearly investment decisions. By studying the

Ecuadorian mechanism, we thus contribute to understanding the specific role of local PB in multilevel government settings. We discuss how the requirements at higher levels need to be well aligned to allow for effective participation at local level. We thereby contribute to the literature on PB by analysing a case of a multi-level PB policy in Ecuador and challenges of multi-level coordination and vertical integration.

2 After reviewing the literature on participation and PB (section 2), we introduce the IAD framework (section 3). We present case study selection and data collection (section 4). In the institutional analysis we analyse the policy processes across government levels, constitutional requirements, and case-specific implementations within two municipalities in Ecuador (section 5). For the empirical analysis, data on 10 years of PB implementation is used to analyse the articulation of collective preferences for municipal PB investments (section 6). We discuss how problems resulting from conflicting constitutional and legal requirements for municipal planning resulted in a hindrance for decentral PB implementations (section 7). We conclude with remarks on lessons learned for PB in multilevel governments (section 8). 


\section{Literature review}

62 Participatory mechanisms increase the direct involvement of citizens in governmental decisions.

63 The very idea of it is closely related to principles of democratic governance (Nabatchi and

64 Blomgren Amsler 2014). Through participation people engage in political decision making and

65 (self-)governance processes regarding their daily lives. Various forms and degrees of such public

66

67

68

69

70

71

72

73

74

75 engagement can be found around the world and at different government levels ranging from local to (inter-)national (Nabatchi and Leighninger 2015; Theesfeld, Dufhues, and Buchenrieder 2017). However, depending on who participates in governance-beyond-the-state and who does not, such mechanism may or may not increase legitimacy and accountability of governmental decisions towards their constituencies (Ostrom 1990; Cabannes and Lipietz 2018). Whether participation enhances representation of collective preferences hinges, inter alia, on the object of decision, and participants (Nabatchi and Blomgren Amsler 2014).

PB mechanisms are a very specific form of public participation, where citizens engage in budgetary decisions - mostly at a decentral level of municipality or (city) district governments and thus combine decentralization with participation, democracy and emancipation (Cabannes 2004; Baiocchi and Ganuza 2014). PB had originally been developed in a leftist, experimental political setting in Porto Alegre, Brazil, in the early 1990s. It has since been implemented in more than 7000 cities worldwide (Dias 2018). Policy diffusion started in Latin America (Porto de Oliveira 2017; Baiocchi and Ganuza 2014), it is now widespread in Europe (Sintomer, Röcke, and Herzberg 2016), and recently started expanding in the United States (Miller, Hildreth, and Stewart 2019). Often these are local, not legally required democratic innovations. Yet there are also more formal implementations. In 2004, the Peruvian government has implemented a top-down PB for all sub-national government levels (Jaramillo and Alcázar 2017; McNulty 2012). While mandating

4 local participation top-down faces challenges, it can be successful when sufficient engagement of 5 local actors can be stimulated (McNulty 2012). 
Various international development agencies promote PB (Bland 2011; Goldfrank 2007;

Goldfrank 2012; Sintomer, Allegretti, and Herzberg 2010; Cabannes 2004). Yet, it is important to note that not every mechanism that is called PB entails active and direct control over budgetary decisions by citizens and merely consultative platforms also go under a PB flag (Goldfrank 2007; Nabatchi and Leighninger 2015; Dias 2018). This may be one reason for the overall mixed empirical results. Some PB studies display promising impacts (Nabatchi and Leighninger 2015). For example, PB implementations have been found to be generally associated with improvements in basic services (Cabannes 2015). PB in Brazil attracted a wide range of participation from both low-income, less-educated and high-income, better-educated people (Pateman 2012). Despite the participation of better-off parts of society, public budgets under PB are more often spent in lowincome neighborhoods (Baiocchi et al. 2006; No and Hsueh 2020) and clientele practices could be reduced (Souza 2001). In some Brazilian PB regimes, education and sanitation spending increased (Touchton and Wampler 2013), infant mortality decreased (Gonçalves 2014), and the number of civil society organizations increased (Touchton and Wampler 2013). New democratic forms of online participation (e-participation) were employed in Belo Horizonte (Coleman, Cardoso Sampaio, and Sampaio 2017). For New York, Russon-Gilman (Russon Gilman 2016) sees both a potential of PB to empower political participation through inclusive governance and a sufficient ability for PB processes to develop rational proposals within city budgets. Calabrese et al. (2020) show how earmarking of revenues determines officials' choice of funding areas within New York's PB. Similarly, PB has been discussed as an inclusive learning arena that builds political capital in terms of multiple sources for democracy education (Kasdan and Markman 2017; Goldfrank and Schugurensky 2019). Such democratic learning is a potential source of the policy diffusion of PB (Porto de Oliveira 2017).

But there are also contradictory results. While there was an observable increase in Brazilian urban PB spending on health and sanitation there is little evidence of positive effects on citizens' 
111 well-being in terms of the Human-Development-Index (Boulding and Wampler 2010). While PB

112 may increase accountability towards citizens through budgetary authority but it may

113 simultaneously undermine other local democratic institutions powers, for example municipal

114 councils (Wampler 2004). In Peru, water and sanitation services did not significantly improve under

115 PB (Jaramillo and Alcázar 2017). An increase in grey infrastructure such as buildings, roads and 116 other 'bag of cement' projects through PB in the rural Andes has been criticised as being preferred

117 by government officials and (international) donor agencies rather than citizens (Cameron 2009). ${ }^{1}$

118 Furthermore, there may be a lack of continuity, for example in externally supported PB initiatives

119 in El Salvador (Bland 2011). A widely varying degree of participation can be observed, down to

120 virtually no participation in Seoul (Im et al. 2013). There can be a lack of actual implementation of 121 proposals resulting from PB, for example in Spain (Font, Amo, and Smith 2016). Furthermore, it

122 is observed that there is an instrumentalization of PB by political promoters in Spain (Bherer et al.

123 2016) or elite entrenchment in Bolivia (Kohl 2003), potentially because it does not fundamentally

124 change existing power relations (Cabannes 2015). Montambeault (2019) argues that beyond the

125 constant participatory rhetoric in Brazilian PB there is a policy change of gradual 126 deinstitutionalization and delegitimization happening on the ground.

127 These varying results call for further studies of PB mechanisms to provide a wider spectrum of 128 empirical results, and a linkage of institutional mechanisms to their scope. In particular, there exist

129 close to no studies regarding the institutional embeddedness of decentral PB in settings with 130 varying competencies of multilevel governments. McNulty's (2019; 2012) analysis of the

131 challenges of centrally required decentral participation makes an important step in this direction

132 but focuses more on top-down participation and democracy than on policy integration and vertical 133 coordination of decentral PB in multilevel governments. This paper therefore sets out to analyse 134 the working of PB within the multi-level government system of Ecuador - where decentral

\footnotetext{
${ }^{1}$ However, this can partly be explained by corresponding competences of the local government for infrastructure development (Cameron 2009).
} 
135 participation in both planning and PB has been constitutionally required since 2008. We next

136 present the institutional analysis framework before proceeding with a justification of case selection.

\section{Analytical framework}

138 The IAD framework has been developed at the Workshop in Political Theory and Policy Analysis

139 (Ostrom 2010; McGinnis and Walker 2010). It is meant as a guiding structure to analyse human

140 interactions and outcomes. It is particularly suited to analyse procedures such as PB processes

141 because it provides a framework to systematically identify various institutional levels that shape

142 the generation of collective choices (Theesfeld, Dufhues, and Buchenrieder 2017). By analysing

143 PB through the lens of the IAD framework we seek to analyse how individual preference turn into

144 public spending decisions in a multilevel government setting.

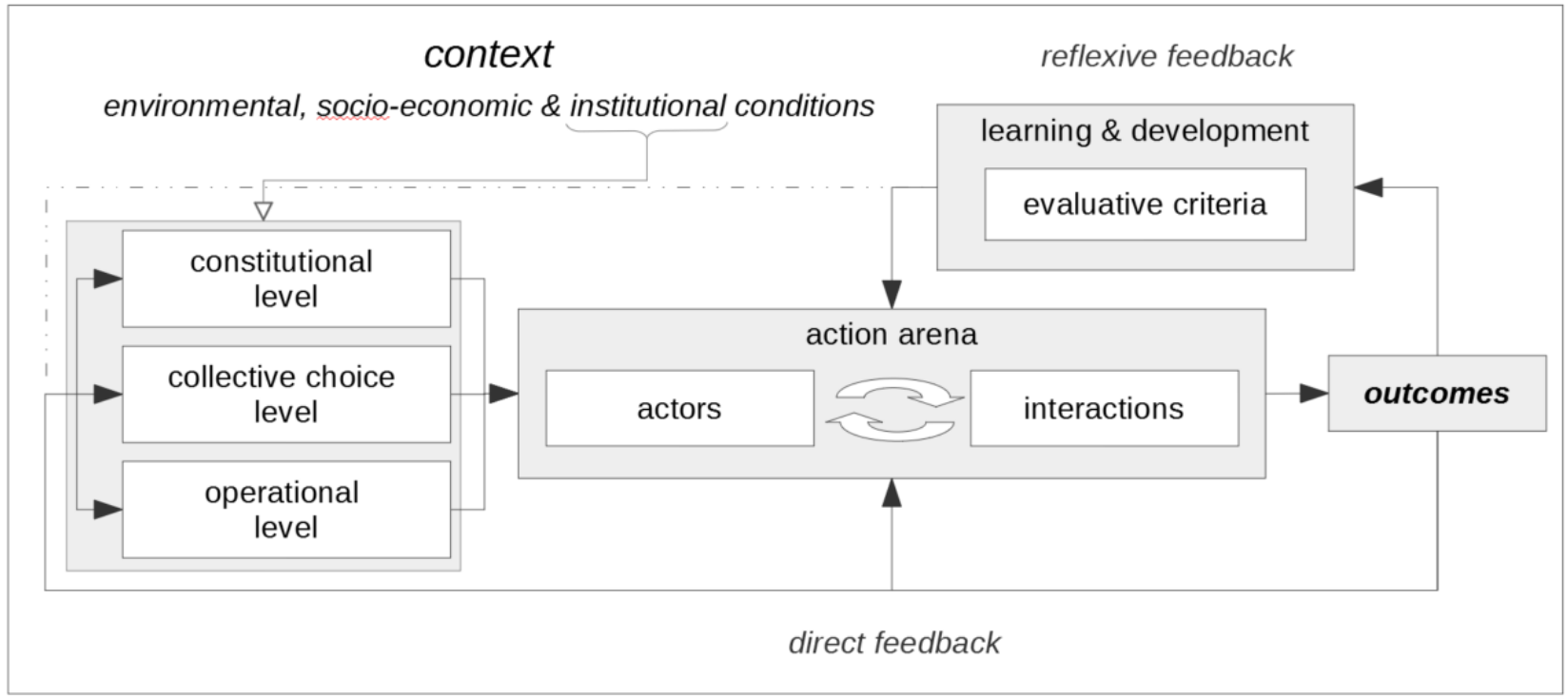

145

146

147

148

149

150

152

151 These contextual variables each influence an action arena where actors interact. The action

Figure 1: Institutional Analysis and Development Framework. Source: adapted from Ostrom (Ostrom 2005; Ostrom 2010) and Andersson (Andersson 2006)

The IAD framework consists of a nested structure of building blocks that in turn may host stacks of further specifications (see Figure 1). The general framework structure has three contextual building blocks that influence the action situation of an actor, environmental or biophysical conditions, socio-economic or communal conditions, and institutional (rules-in-use) conditions. generates outcomes which can either lead to direct changes in (one of) the conditions or the 
153

154

155

156

157

158

159

160

161

162

163

164

165

166

167

168

169

170

171

172

173

174

situation itself. An evaluation of outcomes can influence action situations through reflexive feedback and may indirectly influence contextual conditions. The cyclical view systematizes how human action shapes institutions that in turn shape actions - thus institutional development.

In this paper, we will place emphasis on the rules-in-use that specify the three levels of situations, namely the constitutional, the collective choice and the operational level (Ostrom 2005). These levels do not fully correspond to different levels of government but they provide a focus on both actual implementation and rules in use. The IAD framework thereby allows us to specify the various levels of institutional rules that shape how PB are conducted, who participates in the action arena, and specify and analyse outcomes of the PB processes, while taking institutional learning into account. Accordingly. it also allows to identify where higher level requirements conflict with local practices. We track the stages of policy process from early PB implementation to maturation and scaling up to a national requirement on all levels, through the lens of IAD and with a focus on rules in use at different levels, and practices on the ground.

\section{Case study selection and data collection}

\section{Case selection}

Ecuador is a case of a PB implementation at national scales within a multilevel government structure. Although first pilots were implemented before PB became a nation-wide constitutional requirement in Ecuador in 2008, we start our analysis at the overarching constitutional, nationwide level which was at least partly influenced by the first implementations of early movers and thus constitutes institutional learning (Ortiz Crespo 2008). It thus allows to study the embeddedness of local PB implementations within a wider constitutional framework and thus makes inference on the scale and structural limits of local empowerment. The Ecuadorian case has been studied (Nagua Bazan 2014; UN-Habitat 2009; Curichumbi Yupanqui 2015) but only very little information is yet available in the international scientific literature in English (except for the notable exception of the Cotacachi PB, see Porto de Oliveira 2017). 


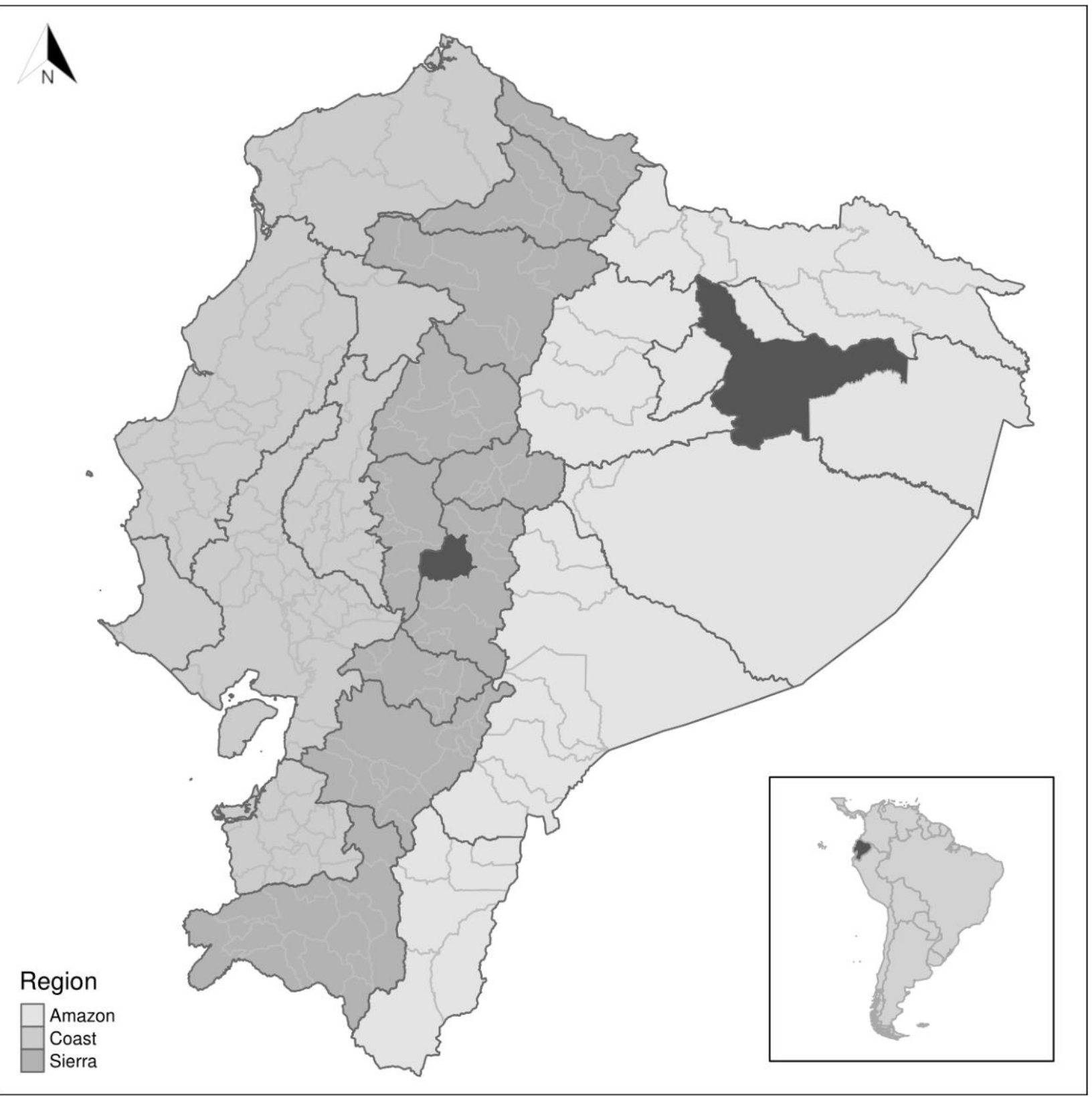

Figure 2: The location of the two cantonal case studies in Ecuador. The small dark one is the Andean Cantón Colta in Chimborazo Province, and the large dark one the Amazonian Cantón Francisco de Orellana in the Province of Orellana. Dark lines delineate provinces and lighter gray lines cantonal boundaries. Galapagos Islands are omitted in the large map. Regions are not jurisdictions but geographical regions. Source: authors' elaboration based on (Global Administrative Areas Database (2018).

To study the implementation within a multilevel government we chose two case studies that were among the first pilots to implement $\mathrm{PB}$ on the ground and went through a transition once the 2008 constitution was in place. Both Ecuadorian municipalities, Colta in the Ecuadorian Andes, and Coca in the Ecuadorian Amazonas, were among the first of 28 other municipalities and two location of the selected case studies within Ecuador. The Andean municipality, Colta, has first 
190

191

192

193

194 195

implemented the municipal budgeting in 2003. In the Amazonian municipality, Francisco de

Orellana, commonly called El Coca, PB was first implemented in 2004.

For the analysis we make use of a most different systems design (Anckar 2008). The two case studies share conceptual commonalities but differ in concrete implementation. The two municipalities are similar in terms of PB duration. They are, however, quite different in terms of regional location, age of settlement, and other factors (see Table 1 in Data collection). Variations in multiple dimensions such as population, resource endowments, level of basic needs satisfaction, infrastructure and geographical location in the Amazon and in the Andes, respectively, allow to study resulting differences in preferences expressed through PB (see Data collection). Commonalities in public spending decisions can thus be assumed to a general characteristic as they can arguably not be rooted in the different circumstances. Thus, if we can observe similar preferences between cases, the most different systems design assumes that this cannot be due to their differences (Anckar 2008). We nevertheless cross-check such inference with further qualitative information. Local responses to the 2008 constitutional requirements are important as the requirement is literally the same for both municipalities. Hence, if we can observe similar responses this can be assumed to be a consequence of the changing institutional regime. The study thereby exemplifies local PB implementations and their response to higher level reforms. The most different systems design thereby showcases the different forms of locally initiated, by now constitutionally embedded PB cases.

\section{Data collection}

The analysis of the institutional design of the PB mechanisms such as legal and administrative requirements is based on a review of laws, codes, the constitution, and secondary publications. Data on the implementation at cantonal level was collected in situ, during several field trips over a period of seven month in 2017-18. After applying for research and data use permissions from the majors of the municipalities, we have conducted several unstructured interviews to deepen our 
215 understanding of the specifics of the local PB implementations. In Colta we conducted 2 interviews

216 with the mayor, 3 interviews with administrative staff, and 4 interviews with community members

217 in Columbe Parroquia. These interviews were around 20-60 minutes. In Coca we conducted 3

218 interviews with administrative staff of 30-90 minutes each. The imbalance of interviews between

219 Colta and Coca can be explained by better written documentation in Coca and thus a lower need to

220 conduct additional interviews. Furthermore, we collaborated with local administrative staff to

221 collect the annual public spending allocated through PB. We have used the archived yearly PB

222 reports of the municipal assembly in Coca from 2004 to 2013 that give details on the decision-

223 making processes in the corresponding years and allocated budgets. For Colta, we used the yearly

224 internal balance sheets of the municipality from 2004 to 2013. We included those public

225 investments that could be attributed to the parochial districts but no cantonal overhead.

226 This way, we built a panel data set on yearly municipal PB investments in the boroughs of both

227 Coca and Colta from 2004 to 2013. Since budget functions (investment areas) were not consistent

228 across municipalities or even years, we classified the PB investments into 12 public function

229 investment areas to facilitate comparability: i) water management including drinking and waste

230 water infrastructure, ii) municipal infrastructure such as communal, parochial and cantonal

231 buildings, and cemeteries, iii) road infrastructure, iv) electricity and communication infrastructure,

232 v) educational infrastructure such as schools and capacity building centers, vi) sports infrastructure

233 such as sport grounds, vii) public health infrastructure such as hospitals, viii) tourism development

234 such as information and reception centers, ix) productive sector support such as storage centers and

235 local market infrastructure, $\mathrm{x}$ ) cultural policies including traditional craft-work support and local

236 churches, xi) environmental protection such as soil conservation and green infrastructure, and xii)

237 security such as local police stations and natural disaster warning systems. Furthermore, we

238 classified the investments according to whether they have been made in rural or urban zones. We

239 compute the shares of PB investments for both the rural and urban zones among the 12 public 
240 functions. The data is a balanced panel with observation over 10 years for the two municipalities

241 with two zones (urban and rural) each and shares for the PB investments among the 12 public

242 function classifications. The underlying dataset of a total of 2509 PB projects (1129 in Coca and

2431380 in Colta) can be found in the Supplementary Materials. Table 1 provides an overview of

244 variables we consider in our qualitative comparative analysis.

245 Table 1: Socio-economic characteristics of the two municipal case studies.

\begin{tabular}{|c|c|c|}
\hline & Colta & El Coca \\
\hline Area & $834 \mathrm{~km}^{2}$ & $7.048 \mathrm{~km}^{2}$ \\
\hline Altitude & $3.212 \mathrm{~m}$ a.s.1. (mean) & $514 \mathrm{~m}$ a.s.1 (mean) \\
\hline Establishment & August 01,1944 & April 30, 1969 \\
\hline $\begin{array}{l}\text { Parroquias } \\
\text { (districts) }\end{array}$ & $\begin{array}{l}2 \text { urban: Cajabamba, and Cicalpa and } 4 \\
\text { rural boroughs: Cañi, Columbe Juan de } \\
\text { Velasco, Santiago de Quito; there are } 11 \\
\text { urban quarters in the cantonal and parochial } \\
\text { cities and } 236 \text { rural communities (2014). }\end{array}$ & $\begin{array}{l}1 \text { urban: Puerto Francisco de Orellana (cantonal } \\
\text { capital) with } 7 \text { urban quarters and } 11 \text { rural boroughs: } \\
\text { El Dorado, Taracoa, Dayuma, Inés Arango, García } \\
\text { Moreno, La Belleza, Nuevo Paraíso, San José de } \\
\text { Guayusa, San Luis de Armenia, Alejandro Labaka, El } \\
\text { Edén with } 287 \text { communities (2014) }\end{array}$ \\
\hline Population 2010 & $\begin{array}{l}44,971 \text { ( } 5.14 \% \text { urban and } 94.86 \% \text { rural), } \\
\text { Indigenous population } 26 \%\end{array}$ & $\begin{array}{l}132,654(55.95 \% \text { urban and } 44.05 \% \text { rural }) \text {, Indigenous } \\
\text { population } 87 \%\end{array}$ \\
\hline Population trend & more or less constant (since 2001) & $\begin{array}{l}\text { strongly positive (until the oil price shock of late } 2014 \\
\text { leading to employment losses) }\end{array}$ \\
\hline $\begin{array}{l}\text { Population with } \\
\text { unsatisfied basic } \\
\text { needs }\end{array}$ & $93,2 \%$ (slightly decreasing) & $85 \%$ (decreasing) \\
\hline Ethnicities & mestizo, Kichwa (Puruhá) & $\begin{array}{l}\text { mestizos, Kichwa, Huaorani, Shuar, and } \\
\text { afroecuatorian }\end{array}$ \\
\hline $\begin{array}{l}\text { Gross Value Added } \\
2010\end{array}$ & $\$ 48,591,000$ & $\$ 3,329,358,000$ \\
\hline Main sectors & agriculture, education, transport \& ICT & $\begin{array}{l}\text { natural resources (crude oil), manufacturing, public } \\
\text { administration }\end{array}$ \\
\hline Main land use & $\begin{array}{l}\text { paramo highland including native shrub } \\
\text { and forest remainders }(40 \%) \text {, crop and } \\
\text { livestock agriculture }(34 \%)\end{array}$ & $\begin{array}{l}\text { natural rain forest types }(75 \%) \text {, cultivations including } \\
\text { plantations and grassland }(13 \%)\end{array}$ \\
\hline
\end{tabular}

Sources: UN-Habitat (UN-Habitat 2009), Banco Central del Ecuador (Banco Central del Ecuador 2017), Ministerio Coordinador de Desarollo Social (Ministerio Coordinador de Desarollo Social and Minsterio Coordinador de Desarollo Social 2017), and municipal development plans (GADM Orellana 2014; GADM Colta 2014).

\section{Institutional analysis of participatory budgeting mechanisms in Ecuador}

247 First municipal pilots were implemented from as early 2003. PB became a nation-wide 248 constitutional requirement in Ecuador in 2008. We employ the IAD framework to analyse the 249 general functioning of PB on various government levels. We start the analysis at the constitutional

250 level that formalized and unified PB requirements across the nation. For collective choice and 251 operational level, we focus on two municipal PB mechanisms that i) were among the first pilots 252 and ii) went through the pre- and post-constitutional PB requirement phases (see Case selection). 
253 The Constitutional level determines the general frame within which the collective choice rules

254 are crafted (Ostrom 2005). In 2007 the Ecuadorian government initialized the writing of a new

255 constitution through invoking an elected constitutional assembly after a successful referendum on

256 the issue (Ortiz Crespo 2008). The new constitution was approved by the electorate in 2008 through

257 another referendum. Article 100 specifies civic participation on different government levels, and 258 paragraph 3 calls for the elaboration of PB mechanisms at all government levels - constituting a 259 bottom-up institutional learning as this follows the early-stage pilot implementations at municipal 260 and provincial level. In 2010, the Organic Law of Civic Participation establishes that PB 261 mechanisms shall be open to all interested parties and citizens but are subject to development plans 262 of the local planning council (Art. 68). PB are to be implemented immediately at lower government 263 levels and progressively at the national level (ibid.). Accordingly, Article 8 of the 2010 Organic 264 Code for Planning and Public Finance establishes that every government level defines its own PB 265 procedure within their respective competencies. Thus, the 2011 Organic Code of Territorial 266 Organization, Autonomy and Decentralization (COOTAD) establishes a new regional organization 267 and specifies competencies and functioning of the so called autonomous decentral governments 268 meaning the i) regional, ii) provincial, iii) cantonal or municipal, and iv) parochial or borough governments (from subnational to most decentral). The code, inter alia, specifies that within exclusive municipal respectively cantonal competencies are, among others, land use, urban transport, waste and drinking water management, waste management, environmental remediation, 272 fire management, infrastructure for health, education, culture, and sports, and cultural heritage 273 preservation. Furthermore, it specifies that local assemblies or corresponding participatory organ 274 shall prioritize annual public investment within budgetary limits and according to (local) 275 development plans and territorial statutes (Art. 238).

276 The local development plans are to be developed participatorily and formulate the indicators 277 against which the performance of municipal administration shall be assessed - with technical 
assistance by the national planning authorities (Senplades 2014; 2016). Hence, the municipal

Development and Territorial Order Plans need to define goals and target indicators for longer planning horizons such that they basically set investment priorities and thereby limit the room for yearly PB decisions. A 2017 proposal for an Organic Code for the Civic Participation System and Social Control aims at establishing a rule that at least 15 per cent of the investment funds at each government level are to be distributed through PB. It furthermore called for a clearly defined methodology of PB at different government levels through the Council of Civic Participation. Yet, this has clearly not been implemented on all government levels and is under ongoing development (Senplades 2009; 2013; 2014; 2016). In particular, the to be established regional governmental level has not yet been formed. There are not yet many operating provincial PB mechanisms. Not all municipalities have established PB. There is not even consistent information how many and what percentage of Ecuadorian municipalities use PB but evidently implementation on the ground is still rather patchy. Institution building is under way and municipalities respond differently to these dual requirements of long-term planning and yearly PB. Civic participation in Ecuador now needs to balance between requirements for more long-term territorial planning and more flexible yearly investment decisions through PB. In fact, the requirement for long-term planning has created challenges for the yearly local PB implementations. It grants decentral authority on specifying PB implementation procedures but requires that the investment decisions must be in line with the local development plan priorities. It is crucial to note that these rules are in clear conflict or at least have been interpreted in different ways such that varying implementations on the ground resulted. We return to this point as its consequences crystalize at the local government level.

At the collective choice level, rules define who is eligible for participation and how the institutional mechanism functions (Ostrom 2005). The collective choice level rules for the municipal PB were formulated (even though not necessarily explicit as a formal institution) even before the constitutional reform and were changed after the constitutional level rules changed in 
303 2008, partially resulting in substantial changes in local PB once the formal constitutional

304 requirements for long-term planning were officially implemented. In both municipalities, the PB

305 implementation was preceded by a consultative and partly participatory formulation of local 306 development plans which served both as (i) an assessment of the current state and future needs of 307 the investment planning, and (ii) a strategic planning instrument (GADM Colta 2001; GADM 308 Orellana 2002). The PB processes were then institutionalized through municipal ordinances 309 because there was not other legal basis for the PB innovation as a means for prioritizing annual 310 investments. Yet, the amount of funds distributed through PB, the criteria for allocation within the 311 municipality, and the bodies that were involved in the PB processes are different in both 312 municipalities (see also subsequent analysis of the operational level). The most interesting 313 difference at the collective choice level is however the variation in responses to the simultaneous 314 constitutional level requirements for both long-term municipal development planning and PB. The 315 double requirements of long-term planning and somewhat vague PB specifications have led to 316 institutional diversification across both municipalities. Coca rather opted for a participatory long 317 term-planning implementation. This did not entirely stall public participation but substantially 318 decreased the frequency at which participation in local public spending decisions are taken. In Coca 319 the first local development plan has been formulated in 2014 and was valid until 2019 (GADM 320 Orellana 2014). This literally marks the end of a yearly PB implementation in Coca at community 321 and quarter level and allows participation in the longer-term development planning only. Yearly 322 budgets are now decided in the cantonal assembly (which is the official body for civic participation 323 but is constituted by elected representatives). In Colta, however, the municipality continues to 324 implement yearly PB mechanisms. However, in order to comply with the requirement of investing 325 according to the investment priorities specified in the local development plan (GADM Colta 2014), 326 projects identified through the PB mechanism will receive higher priority if they are in line with 327 the local development goals. This is to say the constitutional requirement for longer-term planning 
stipulated a diversification of collective choice level rules for PB mechanisms across the two municipalities but led to a partial re-centralization in both cases.

The operational level decisions determine budget allocations in terms of rather specific management rules such as setting locations for the PB meetings, speaking rules, or schedules are defined. While this may determine who is actually participating, especially in remote areas, we could rather observe practices than analyse formally instituted rule systems. In Colta, at first the entire municipal (cantonal) investment fund was distributed among communities (villages) based on the population (UN-Habitat 2009 and interview with the mayor in Colta). Up until 2007, each community could decide upon its own priorities, but it left them with little budget to decide upon (in the range of a few thousand US\$). PB meetings were held at municipal level and communities could send six democratically elected delegates to the municipal PB meetings (although not every community participated). Since 2008 , the priorities were assessed in a more decentral way at municipal and quarter meetings instead of a municipal (cantonal) meeting. The number of directly involved participants thus increased significantly (UN-Habitat 2009). After the municipal elections under the new constitution in 2009 , the communities within parroquias were grouped into sectors, and PB budgets were distributed among parochial sectors based on population, while a portion of the investment fund was withheld by the municipal government for strategic long-term investments within the canton (interviews with mayor and administrators in Colta). The grouping of municipalities into sectors and the distribution of funds among sectors nevertheless meant that PB projects grew in investment amounts (ibid.). Thus, larger projects could be prioritized but not necessarily every community within a sector benefited every year. This required coordination between municipalities within a sector (ibid.). While this coordination happened informally and in different forms between municipal representatives, PB meetings of sector delegates at parochial level or its urban equivalent of quarters were now the most decentral level for PB meetings (interviews with communal members in Columbe). The municipal government in Colta 
353 furthermore solved the requirement of meeting development planning priorities by withholding a

354 share of municipal investment budgets for strategic investments and a simultaneous grouping of 355 municipalities into sectors such that PB projects still grew in size. Nevertheless, in response to the 356 new planning laws, Colta partly re-centralized investment decisions after municipal elections in 3572014 by giving higher priority to projects that are in line with the development plan priorities but 358 continues participatory budget decisions (interview with mayor in Colta). According to community members, these are rather public events informing the constituency about the investment decisions taken rather than ,truely“ deciding upon budgets. This procedure gradually empowered the role of the parochial and cantonal assemblies and thus transformed communal participation with representation in assemblies. The project list, however, that the assemblies use to prioritize 363 investments is based on suggestions from (groups of) communities within the parroquias 364 (interviews with communal members in Columbe).

In Coca there was a strategic development plan from 2002 to 2012 (GADM Orellana 2002) but public investment decision were taken through yearly PB. 80 per cent of the municipal investment funds were distributed through PB among the parroquias and urban quarters (UN-Habitat 2009, and yearly PB reports). The PB funds were distributed to 80 per cent territorially (35 per cent to rural areas and 65 per cent for urban quarters) and 20 per cent were allocated to 15 thematic round tables according to management capacity and budgetary needs (interviews with administrators in Coca). The territorially distributed funds were distributed according to population, unsatisfied basic necessities, a priority for those locations that had not benefitted the years before, oil-production impacts, in case of rural area remoteness, and for urban zones the rate of civic participation in PB

374 meetings (yearly PB reports and interviews with administrators). PB meetings were held at 375 parochial and quarter level and consisted of democratically elected delegates from parochial 376 communities and from within the urban quarter (ibid). These PB meetings proposed (a list of) 377 projects to be implemented. The proposed projects were ranked according to points for number of 
beneficiaries, priority areas, urgency, inter-communal alliances, necessities, positive relation to cantonal development plan communities, and others (ibid.). The resulting list of projects entered the yearly budget plans until the budgetary limits were reached. The national requirement for 10year development planning implies that strategic investments need to be prioritized. In Coca, this led to a fully fledged re-centralization of yearly budgetary decisions from PB meetings to the municipal government, as the development plans need be executed and adhered to (interview with administrative staff). Since municipal elections in 2014, municipal investments are determined through the cantonal development planning by the cantonal assembly instead of yearly PB meetings (Gobierno Municipal de Orellana 2014, and interviews with administrative staff). Public participation for budget decisions is now employed through a not yet formally specified participation in strategic development planning instead of through yearly PB meetings.

Both municipalities reacted in similar ways to the national law on development planning by (partly) re-centralising the investment decisions. This indicates that there is a conflict between the planning laws and the constitutional PB requirements that could not be solved without trade-offs. We will return to an interpretation of this in the discussion.

\section{Empirical analysis of collective preference formulation}

PB mechanisms have been in place in both case study municipalities for at least 10 years. In this section we inductively analyse how collective preferences shaped the budgetary allocations through PB at an operational level, eliciting the preferences articulated through PB. As such, the analysis is limited to the time of PB operation during the period 2004-2013. We analyse this cases by both descriptive quantitative and qualitative interpretative comparisons (Levy 2008).

We display how the PB budget has developed over time for the two municipalities in order to clarify the budgetary constraints for the collective choice arrangements. We show the investments in both rural and urban zones and how the PB budget was distributed among public functions to map the elicited local collective preferences. 

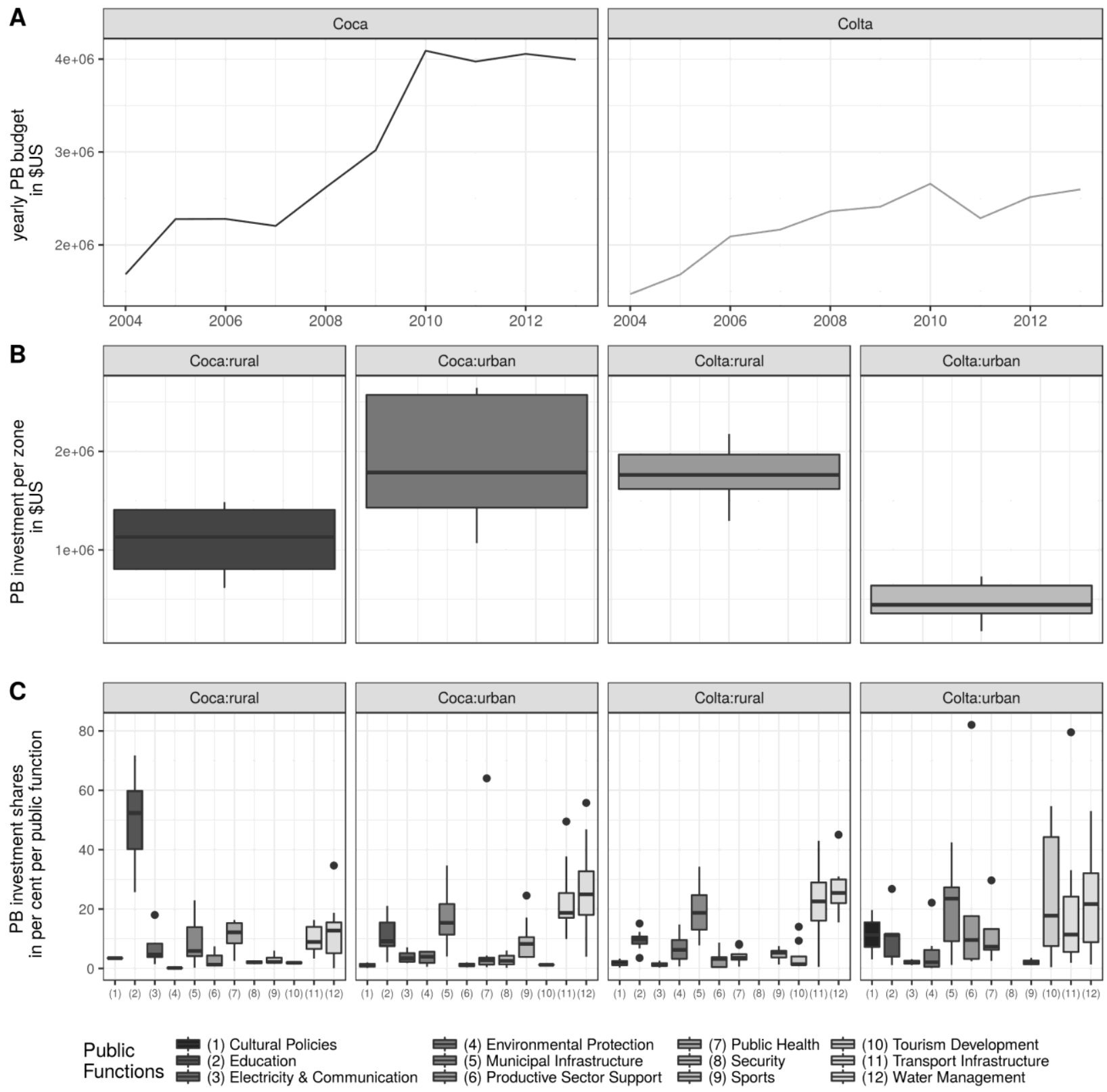

Figure 3: Participatory Budgeting comparisons between municipalities with regard to: A) yearly PB budget development; B) total investments per rural vs urban zones, and C) investment shares per public function. Investment are given in \$US. The boxplots in B) and C) display the median value across years at the bar, 25 and 75 per cent quartiles of the data as the box, and outliers as points. Source: authors' computation based on municipal PB reports.

Panel A in Figure 3 shows that the municipality of Coca always had a larger PB budget which was furthermore growing quicker than over time the PB Colta budget (rising from about 1.6 million US\$ in 2004 to about 4 million in 2013 in Coca, and from almost 1.5 million in 2004 to almost 2,6 million in 2013 in Coca). This is mainly due to high revenues from crude oil production in Coca

411 (see also Table 1). From around 2010 both PB budgets took a slight drop and remained on a constant 
412 level until 2014 which is related to the 2008 economic crisis that hit the municipalities in Ecuador

413 a bit later than the national level. Panel B shows that while in Coca larger yearly amounts have

414 been invested in the urban zone, it is to the contrary in Colta, where comparatively little has been

415 invested in the urban zones. The fact that PB investment sums in urban Colta are lower than

416 anywhere else can be explained by a) the relatively high share of rural population in Colta, and the

417 correspondingly high PB distribution to rural areas (see Table 1), and b) that many of the direct

418 municipal government investments according to strategic development goals were made in urban

419 Colta which substituted the need for infrastructure investment (interview with the mayor in Colta).

420 Panel C display the distribution of yearly investment shares in per cent among 12 public functions

421 within the municipal competence across the analysed 10 years. From the median bars we can see

422 that preferences differ among both municipalities and zones. We can thus observe that different

423 preferences are articulated across both municipalities and urban and rural zones.

424 There are indications that these investments are in line with local preferences. First, we record

425

426

427

428

430

431

432

433

434

435

436 several occasions where the local interviewees expressed that needs are met by prioritized investments. This is evidenced by either direct expressions of own interest in the case of community members in Colta for water and road infrastructure, or the explanation of educational needs of rural communities by administrative staff in Colta. As these interviews are small $N$, qualititative sources of information, they are not necessarily representative. They can however provide indications from different type of actors (see Data collection). We can further triangulate through a descriptive comparison based on the most different case study design by comparing the developmental situation in the respective municipalities (see Table 1). There are similarities in terms of multi-ethic populations but different ethnicities (except for Mestizos). Furthermore, bio-geographically and in terms of land use, Andean Colta and Amazonian Coca largely differ. Comparing the four zones across the two case studies, the urban zone in Coca and the rural zone in Colta appear to have greater commonalities than the two zones within Coca and Colta to each other. This indicates that 
437

438

439

440

441

442

443

444

445

446

447

448

450

451

452

453

454

455

456

457

458

459

460

461

rural Colta in the Andes and urban Coca in the Amazon may have similar development needs or at

least that citizens in both municipal zones value similar types of public goods similarly. This apparent similarity, however, is partly superficial once preferences are cross-checked on the ground. Overall, grey infrastructure has indeed a high priority, but this is also conditional on the institutional design in the case study, where the municipal investment fund is distributed through PB. Investment is typically classified as expenditure into capital (basically infrastructure owned by the municipalities), while wages are running expenditure which do not classify as eligible under PB. This may partly explain the observed high preferences for grey infrastructure across zones and municipalities (Cameron 2009) - when compared to say educational spending for employing teachers (which is not possible through PB). Our interviewees, however, did not voice any objections against the institutional limitations that allowed only a certain type of infrastructure investment. Rather, roads and school buildings seemed to have an important value for the communities in Colta and Coca. Furthermore, the limitation of what type of projects could be prioritized seemed to be taken as a given across participants - at least no concerns where voiced.

In terms of prioritized PB investments urban Coca and rural Colta have in common is that they have a high expressed preference for water infrastructure investments. At the local level, urban Coca has a need for both clean drinking water and adequate wastewater treatment whereas rural Colta faces problems of providing drinking water to remote mountainous communities (both based on an assessment of the PB project data base, see supplementary data, and interview data). Lots of communal efforts go into securing constant and clean water supply. Furthermore, there is relatively good road infrastructure, and thus accessibility in both sites. This may explain the relatively high expenditure in this regard (see Figure 3, Panel C) as an established infrastructure comes with maintenance costs. Field trip observations and interviews confirm that there are in fact not just maintenance works but continuous investments in infrastructure improvements ongoing in both localities. This reflects expressed needs for commuting and desired reductions in travel time 
462 (interview with communal members in Colta). The high municipal infrastructure investments do

463 not differ so much at the local level. It is mainly community buildings that are built with these

464 investments whether rural "casas communales" or urban communal "casas barriales" (project

465 database). There is, however, a relatively high share of expenditures for cemeteries in rural Colta

466 (project database). Both sites have relatively high spending on environmental protection, mainly

467 dealing with waterbody protection (Coca) and erosion control (Colta). This reflects the two

468 environmental resources most exposed to contamination and overuse (GADM Orellana 2002;

469 GADM Colta 2001). While there are thus seemingly high correlations between developmental

470 needs in both rural Colta and urban Coca, the very nature of expressed investments needs differs

471 to some extent at the local level. The needs in rural Coca, differ greatly, not just in nature but

472 significantly in quantitative terms. There is a very high demand for educational investment -

473 mainly in school buildings for instruction and in some cases teacher housing. According to

474 interview data with local administrative staff in Coca, this is mainly due to difficult school

475 accessibility in the relatively sparsely populated Amazonian rural areas without much road

476 infrastructure. This comes with long boat travels of school children along the Amazonian rivers

477 that parents wish to reduce. Educational infrastructure thus heavily outweighs all other

478 development investments. In second and third, yet far off places, come (drinking) water

479 management and public health (local sanitary and health care buildings), respectively. Urban Colta,

480 in contrast, has high articulated preferences for municipal infrastructure, mainly in the form of a

481 new cantonal town hall. This may partly be due to relatively secure and well-paid jobs for the local

482 administration and its growth therefore provided opportunities, and because construction adds yet

483 more labour demand (both pointed out by some interviewees in Colta). People may thus have voted

484 for corresponding investments for their own employment chances. This is followed by high but

485 varying investments in water management and tourism infrastructure. These articulated

486 developmental needs are partly related as a high share of these investments went into the recovery 
487 of the "Laguna de Colta", the local waterbody and the construction of adjacent tourism

488 infrastructure to capitalize on scenic beauty (as evidenced by project database and field visits).

489 The differences within the cantons indicate that the PB mechanism allowed participants to 490 express different needs, for example across urban and rural zones. Interview data seems to 491 corroborate a relatively effective PB functioning in terms of preference satisfaction. Yet, through 492 the institutional and empirical analyses, we can observe an active policy experimentation at the 493 local level during the piloting phase and a less inclusive PB implementation once higher-level 494 requirements are introduced. This has implications for legitimacy and effectiveness of PB.

\section{Discussion of institutional development of PB in Ecuador}

496 Decentral governments are closer to the people and could thus provide public functions in line with 497 the local preferences (Oates 1972; Faguet 2014). Participation can enhance democracy (Fung and 498 Wright 2001) but faces challenges, in particular when ordered from above (McNulty 2019). 499 Participating in budgetary decisions holds many promises but has mainly been experimented with 500 at decentral levels. The Ecuadorian case thus provides opportunities to improve our understanding 501 of decentral PB embedded within multi-level governments. So far, the successful cases have been 502 reported from decentral PB, e.g. in Brazil (Touchton and Wampler 2013; Gonçalves 2014) or the 503 USA (Russon Gilman 2016), see also Nabatchi and Leighninger (2015). When participation is 504 ordered from above, this can create empty mechanisms that may not necessarily involve civil 505 society participation (McNulty 2019). Here, we contribute evidence showing that initial PB pilots 506 in Ecuador prioritized investments projects through very localized PB meetings. Following several 507 municipal pilots, the 2008 constitutional reform in Ecuador required all government levels to 508 implement PB. This constitutes a case of a bottom-up institutional development. The constitutional 509 reform, however, led to a (partial) recentralization of the investment decision making power away 510 from local meetings to cantonal assemblies. 
511 The laws clearly state require both municipal planning procedures and PB processes. The

512 municipal development plans serve the purpose of formulating the mid to long-term goals

513 participatorily and the yearly budgets are subject to the development plans (Senplades 2010). This

514 means that, by institutional design, the long-term planning trumps yearly PB. This is in line with

515 higher government level coordination of lower government level performance and a general 516 prioritization of planning over participation where development priorities have been formulated by

517 the planning agencies rather than by the citizens (Senplades 2009; 2013). This corroborates the 518 observed tendency for (re-)centralization despite participatory framings of the Ecuadorian 519 government under the 2008 constitution (McNulty 2019, Supplementary Material). It also 520 coincides with a finding from Montambeault (2019) who observes a gradual policy change within 521 local PB practices in Belo Horizonte that delegitimized participatory outcomes. As such, the 522 Ecuadorian case stands for a rise of PB through local experimentation and a subsequent fall through 523 conflictual demands in scaling a local policy up to the national level. Successful PB pilots were 524 stalled by central planning requirements despite a constitutional requirement for their continuation 525 at all government levels. The intention was therefore probably not hampering local implementation. 526 However, requirements for vertical coordination and longer-term development planning imposed 527 severe challenges for the local PB practices. Conflicting requirements from higher level 528 governments regarding long-term planning and PB led to a faulty PB implementation. Here, we 529 argue that this is a consequence of institutional complexity in terms of simultaneous requirements 530 for vertically coordinated development planning and PB requirements at all levels (see Figure 4 531 for a graphical representation of our argument). The requirements for concerted efforts in terms of 532 national development impose limits to the devolution of all budgetary decisions to the local level. 533 This requires coordination of development planning and rules and scope for corresponding PB 534 mechanisms across levels. It is a challenge that needs to be solved if municipal PB are to be 535 implemented successfully - as required by the constitution and subsequent legislation. 


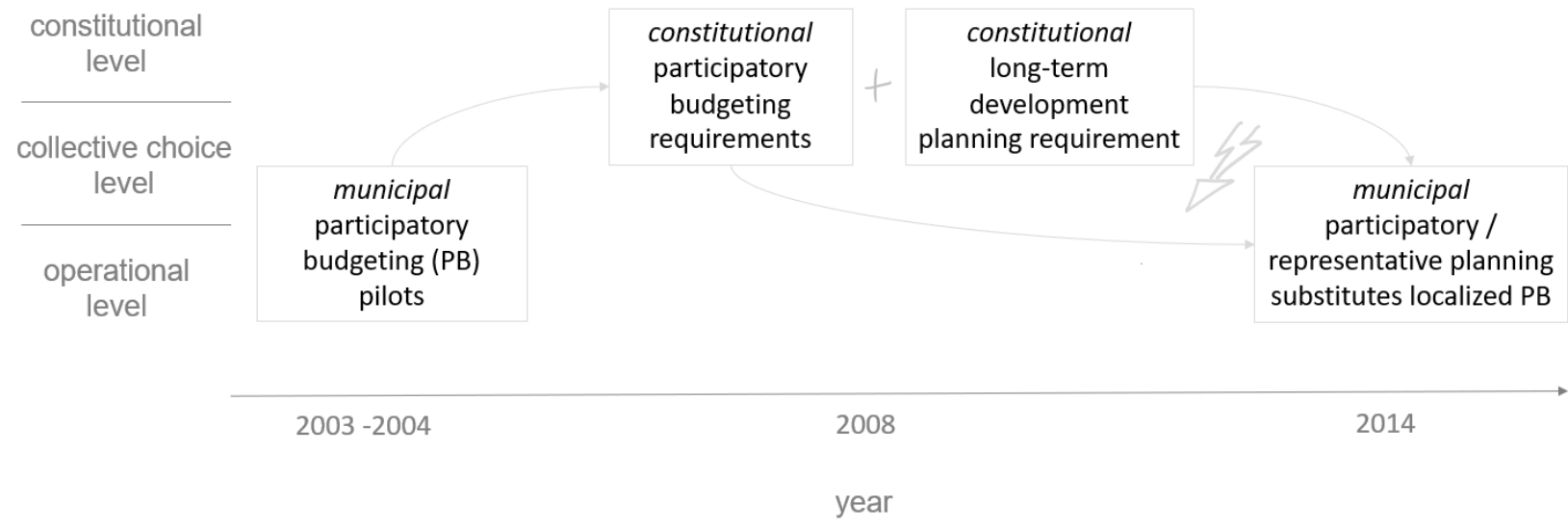

Figure 4: Stylized institutional development of the Ecuadorian participatory budgeting (PB) mechanism over time. It displays that there were partly conflicting requirements on municipal planning and budgetary processes from higher level government laws that led municipalities to opt for planning rather than PB requirements. Source: own representation.

541 The literature on institutional complexity can partly help understanding this phenomenon. For 542 the case of South Africa Koelble and Siddle (2014) argue that decentralization failed because local 543 governments were facing complex constitutional and legal requirements they were not equipped to 544 meet. The lack of success in implementing decentral participation in South Africa could thus well 545 be explained by a lack sufficient organizational complexity to face institutionally complex 546 requirements. In case of complex multi-level government requirements, local government staff 547 needs to be prepared to implement decentral. Ewens and van der Voet (2019) show that the number 548 of municipal departments has a positive relation with participatory innovation among German 549 municipal PBs. This measure may in turn be correlated with specialized staff and thus 550 administrative capacities. Functional differentiation and specialized staff can thus increase 551 preparedness and innovation at the local level. For the analysed Ecuadorian PB pilots a ten-year 552 implementation had arguably created corresponding local capacities. Before the constitutional 553 reform both municipalities also had development plans (GADM Colta 2001; GADM Orellana 554 2002) but these rather served a scoping function to look ahead than defining strategic investment 555 priorities. Yet, the new constitution and subsequent legislation additionally required them to plan 556 and participatorily formulate goal indicators against which their performance is centrally assessed. 


\section{Conclusion}

573 We have analysed $\mathrm{PB}$ as a participatory decision-making mechanism for public investment 574 decisions in the Ecuadorian multi-level government structure through the analytical lens of the IAD 575 framework. This allowed to disentangle local practices, collective choice outcomes and 576 constitutional requirements. Both case study municipalities in Ecuador had piloted PB 577 mechanisms. We find evidence that during the time of operation the municipal PB mechanisms 578 expressed locally differentiated preferences in yearly decentral investment decisions. These PB 579 pilots were subsequently scaled up to become a requirement for all government levels under the 5802008 constitution. The municipal cases thus serve as examples of an embedded decentralized 581 implementation within a multi-level PB governance. To ensure policy coherence, the central 
582

583

584

585

586

587

588

589

590

591

592

593

594

595

596

597

598

599

600

601

602

603

604

605

606

607

608

609

610

government simultaneously introduced a national law for vertical coordination of development planning. The law requires municipalities to develop long-term development plans. Despite a participatory formulation of these development plans, the requirements of both long-term planning and local PB introduced complications. To ensure to reach long-term development plans both municipalities recentralized investment decision from $\mathrm{PB}$ assemblies to municipal planning committees. This had detrimental effects on the frequency of participation and the possibility to prioritize municipal budgets through annual local PB participation. However, as PB mechanisms remain to be constitutionally required and there is a need to properly define the relation of municipal development plans and PB mechanisms. Here, the Ecuadorian multi-level system can build upon the successful municipal experiences in implementing PB, while carving out a place for strategic longer-term planning that does not hamper the implementation of the constitutional requirement for annual local participation in budgetary planning.

Acknowledgements: ND is grateful for financial support by the Heinrich-Böll Foundation (grant no. P118873). We furthermore thank the mayors, administrative staff, and people of Francisco de Orellana and Colta municipalities to provide us with information and data.

\section{References}

Anckar, Carsten. 2008. "On the Applicability of the Most Similar Systems Design and the Most Different Systems Design in Comparative Research.” International Journal of Social Research Methodology 5579 (11): 389-401. doi:10.1080/13645570701401552.

Andersson, Krister. 2006. "Understanding Decentralized Forest Governance: An Application of the Institutional Analysis and Development Framework.” Sustainability, Science, Practice, \& Policy 2 (1): 25-35.

Baiocchi, Gianpaolo, and Ernesto Ganuza. 2014. "Participatory Budgeting as If Emancipation Mattered.” Politics \& Society 42 (1): 29-50. doi:10.1177/0032329213512978.

Baiocchi, Gianpaolo, Patrick Heller, Shubham Chaudhuri, and Marcelo Kunrath Silva. 2006. "Evaluating Empowerment: Participatory Budgeting in Brazilian Municipalities.” In Empowerment in Practice: From Analysis to Implementation, edited by R. Alsop, M. Frost Bertelsen, and J. Holland, 94-124. Washington, D.C.: World Bank.

Banco Central del Ecuador. 2017. “Cuentas Nacionales.” https://www.bce.fin.ec/index.php/component/k2/item/763.

Bardhan, Pranab. 2002. "Decentralization of Governance and Development." Journal of Economic Perspectives 16 
611

612

613

614

615

616

617

618

619

620

621

622

623

624

625

626

627

628

629

630

631

632

633

634

635

636

637

638

639

640

641

642

643

644

645

646

647

648

649

650

(4): 185-205. doi:10.1257/089533002320951037.

Bherer, Laurence, J.L. Fernández-Martínez, P. García Espín, and M. Jiménez Sánchez. 2016. “The Promise for Democratic Deepening: The Effects of Participatory Processes in the Interaction between Civil Society and Local Governments.” Journal of Civil Society 12 (3). doi:10.1080/17448689.2016.1215957.

Bland, Gary. 2011. "Supporting Post-Conflict Democratic Development? External Promotion of Participatory

$$
\text { Budgeting in El Salvador.” World Development } 39 \text { (5). Elsevier Ltd: 863-873. }
$$

doi:10.1016/j.worlddev.2010.09.010.

Boulding, Carew, and Brian Wampler. 2010. "Voice, Votes, and Resources: Evaluating the Effect of Participatory Democracy on Well-Being.” World Development 38 (1). Elsevier Ltd: 125-135. doi:10.1016/j.worlddev.2009.05.002.

Breton, Albert. 1998. Competitive Governments: An Economic Theory of Politics and Public Finance. Cambridge: Cambridge University Press.

Cabannes, Yves. 2004. "Participatory Budgeting: A Significant Contribution to Participatory Democracy." Environment and Urbanization 16 (1): 27-46. doi:10.1177/095624780401600104.

Cabannes, Yves. 2015. "The Impact of Participatory Budgeting on Basic Services: Municipal Practices and Evidence from the Field." Environment and Urbanization 27 (1): 257-284. doi:10.1177/0956247815572297.

Cabannes, Yves, and Barbara Lipietz. 2018. "Revisiting the Democratic Promise of Participatory Budgeting in Light of Competing Political, Good Governance and Technocratic Logics.” Environment and Urbanization 30 (1): 67-84. doi:10.1177/0956247817746279.

Calabrese, Thad, Dan Williams, and Anubhav Gupta. 2020. "Does Participatory Budgeting Alter Public Spending? Evidence From New York City.” Administration and Society. doi:10.1177/0095399720912548.

Cameron, John D. 2009. “'Development Is a Bag of Cement': The Infrapolitics of Participatory Budgeting in the Andes." Development in Practice 19 (6): 692-701. doi:10.1080/09614520903026835.

Coleman, Stephen, Rafael Cardoso Sampaio, and Rafael Cardoso Sampaio. 2017. "Sustaining a Democratic Innovation: A Study of Three e-Participatory Budgets in Belo Horizonte." Information Communication and Society 20 (5): 754-769. doi:10.1080/1369118X.2016.1203971.

Curichumbi Yupanqui, Pedro. 2015. "Diseño y Applicación de Un Modelo de Presupuesto Participativo Bajo La Administración Por Procesos En Una Municipalidad Pequeña.” Escuela Politénica Nacional.

De Mello, Luiz R. 2000. "Fiscal Decentralization and Intergovernmental Fiscal Relations: A Cross-Country Analysis." World Development 28 (2): 365-380. doi:10.1016/S0305-750X(99)00123-0.

Dias, Nelson. 2018. Hope for Democracy - 30 Years of Participatory Budgeting. Faro: Epopeia Records.

Ewens, Hendrik, and Joris van der Voet. 2019. "Organizational Complexity and Participatory Innovation: Participatory Budgeting in Local Government.” Public Management Review 21 (12). Routledge: 1848-1866. doi:10.1080/14719037.2019.1577908.

Faguet, Jean-Paul. 2004. "Does Decentralization Increase Government Responsiveness to Local Needs? Evidence from Bolivia.” Journal of Public Economics 88 (3-4): 867-893. doi:10.1016/S0047-2727(02)00185-8.

Faguet, Jean-Paul. 2014. “Decentralization and Governance.” World Development 53: 2-13. doi:10.1016/j.worlddev.2013.01.002.

Font, Joan, Sara Amo, and Graham Smith. 2016. "Tracing the Impact of Policy Proposals from Participatory Processes: Methodological Challenges and Substantive Lessons." Journal of Public Deliberation 12 (1): 1-25. 
651 Fung, Archon. 2006. "Varieties of Participation in Complex Governance." Public Administration Review 66 (SUPPL.

1): 66-75. doi:10.1111/j.1540-6210.2006.00667.x.

653 Fung, Archon. 2015. "Putting the Public Back into Governance: The Challenges of Citizen Participation and Its 654 Future." Public Administration Review 75 (4): 513-522. doi:10.1111/puar.12361.

655 Fung, Archon, and Erik Olin Wright. 2001. "Deepening Democracy: Innovations in Empowered Participatory Governance." Politics and Society 29 (1): 5-41. doi:10.1177/0032329201029001002.

657 GADM Colta. 2001. Plan de Vida y Equidad. Villa La Unión: Gobierno Municipal de Colta.

658 GADM Colta. 2014. Plan de Desarollo y Ordenamiento Territorial 2030. Villa La Unión: Gobierno Municipal de $659 \quad$ Colta.

660 GADM Orellana. 2002. Plan de Desarrollo Estratégico 2002-2012. Francisco de Orellana: Gobierno Municipal de 661 Orellana.

662 GADM Orellana. 2014. Plan de Desarollo y Ordenamiento Territorial 2014-2019. Francisco de Orellana: Gobierno 663 Municipal de Orellana.

664 Global Administrative Areas Database. 2018. "Global Administrative Areas Database.” http://gadm.org/.

665 Goldfrank, Benjamin. 2007. "Lessons from Latin American Experience in Participatory Budgeting." In Participatory 666 Budgeting, edited by Anwar Shah, 91-126. Washington, D.C.: World Bank.

667 Goldfrank, Benjamin. 2012. "The World Bank and the Globalization of Participatory Budgeting.” Journal of Public 668 Deliberation 8 (2): 20. http://www.publicdeliberation.net/jpd/vol8/iss2/art7.

669 Goldfrank, Benjamin, and Aaron Schneider. 2006. "Competitive Institution Building: The PT and Participatory 670 Budgeting in Rio Grande Do Sul.” Latin American Politics and Society 48 (03): 1-31. doi:10.1111/j.1548671 2456.2006.tb00354.x.

672 Goldfrank, Benjamin, and Daniel Schugurensky. 2019. "Participatory Budgeting, Civic Education, and Political 673 Capital.” Encyclopedia of Educational Innovation, 1-6. doi:10.1007/978-981-13-2262-4_37-1.

674 Gonçalves, Sónia. 2014. "The Effects of Participatory Budgeting on Municipal Expenditures and Infant Mortality in 675 Brazil.” World Development 53: 94-110. doi:10.1016/j.worlddev.2013.01.009.

Hinnerich, Björn Tyrefors, and Per Petterson-Lidbom. 2014. "Democracy, Redistribution, and Political Participation: Evidence From Sweden 1919-1938.” Econometrica 82 (3): 961-993. doi:10.3982/ecta9607.

Im, Tobin, Hyunkuk Lee, Wonhyuk Cho, and Jesse W Campbell. 2013. "Citizen Preference and Resource Allocation: The Case for Participatory Budgeting in Seoul." Local Government Studies 40 (1): 102-120. doi:10.1080/03003930.2013.812963.

Jaramillo, Miguel, and Lorena Alcázar. 2017. "Does Participatory Budgeting Have an Effect on the Quality of Public Services? The Case of Peru's Water and Sanitation Sector.” In Improving Access and Quality of Public Services in Latin America. To Govern and To Serve, edited by Guillermo Perry and Ramona Angelescu Naqvi, 105-136. New York: Palgrave Macmillan.

685 Kasdan, Alexa, and Erin Markman. 2017. "Participatory Budgeting and Community-Based Research: Principles, Practices, and Implications for Impact Validity.” New Political Science 39 (1). Routledge: 143-155. doi:10.1080/07393148.2017.1278859. Failure of Decentralization in South Africa." Democratization 21 (6): 1117-1133. 
691 Kohl, Benjamin. 2003. "Democratizing Decentralization in Bolivia: The Law of Popular Participation.” Journal of

692 Planning Education and Research 23: 153-164. doi:10.1177/0739456X03258639.

693 Levy, Jack S. 2008. “Case Studies: Types, Designs, and Logics of Inference.” Conflict Management and Peace

$694 \quad$ Science 25 (1): 1-18. doi:10.1080/07388940701860318.

695 McGinnis, Michael D, and James M Walker. 2010. "Foundations of the Ostrom Workshop: Institutional Analysis,

696 Polycentricity, and Self-Governance of the Commons." Public Choice 143 (3): 293-301. doi:10.1007/s11127-

$697 \quad 010-9626-5$.

698 McNulty, Stephanie L. 2012. “An Unlikely Success - Peru's Top-Down Participatory Budgeting Experience.”

$699 \quad$ Journal of Public Deliberation 8 (2): Article 4.

700 McNulty, Stephanie L. 2019. Democracy from above?: The Unfulfilled Promise of Nationally Mandated

$701 \quad$ Participatory Reforms. Stanford University Press.

702 Miller, Steven A, R W Hildreth, and La Shonda M Stewart. 2019. "The Modes of Participation: A Revised Frame for Identifying and Analyzing Participatory Budgeting Practices.” Administration and Society 51 (8): 1254-1281. doi:10.1177/0095399717718325.

Ministerio Coordinador de Desarollo Social, and Minsterio Coordinador de Desarollo Social. 2017. "Sistema de Indicadores Sociales Del Ecuador.” http://www.siise.gob.ec/siiseweb/.

Montambeault, Françoise. 2019. "It Was Once a Radical Democratic Proposal: Theories of Gradual Institutional Change in Brazilian Participatory Budgeting." Latin American Politics and Society. Cambridge University Press. doi:10.1017/lap.2018.58.

Nabatchi, Tina, and Lisa Blomgren Amsler. 2014. "Direct Public Engagement in Local Government." The American Review of Public Administration 44: 63S-88S. doi:10.1177/0275074013519702.

Nabatchi, Tina, and Matt Leighninger. 2015. Public Participation for 21st Century Democracy. Hoboken, NJ: Jossey-Bass.

Nagua Bazan, Leonardo Javier. 2014. “El Presupuesto Participativo Del Gobierno Autónomo Decentralizado Del Cantón Bahahoyo Ciudadana Con Enfoque de Gobernabilidad." Pontifica Unversidad Católica del Ecuador.

No, Won, and Lily Hsueh. 2020. "How a Participatory Process with Inclusive Structural Design Allocates Resources toward Poor Neighborhoods: The Case of Participatory Budgeting in Seoul, South Korea." International Review of Administrative Sciences. doi:10.1177/0020852320943668.

O’Flynn, Janine. 2007. "From New Public Management to Public Value: Paradigmatic Change and Managerial Implications.” Australian Journal of Public Administration 66 (3): 353-366. doi:10.1111/j.14678500.2007.00545.x.

Oates, Wallace E. 1972. Fiscal Federalism. New York: Harcourt Brace Jovanovich.

Oates, Wallace E. 1999. “An Essay on Fiscal Federalism.” Journal of Economic Literature XXXVII: 1120-1149.

Ortiz Crespo, Santiago. 2008. "Participación Ciudadana: La Constitución de 1998 y El Nuevo Proyecto Constitucional." Iconos. Revista de Ciencias Sociales 32. FLACSO sede Ecuador.

Ostrom, Elinor. 1990. Governing the Commons : The Evolution of Institutions for Collective Action. Cambridge: Cambridge Univ. Press.

Ostrom, Elinor. 2005. Understanding Institutional Diversity. Vol. 132. doi:10.1007/s11127-007-9157-x. Ostrom, Elinor. 2010. "Beyond Markets and States: Polycentric Governance of Complex Economic Systems." American Economic Review 100 (June): 641-672. doi:10.1257/aer.100.3.641. 
731 Pateman, Carole. 2012. "Participatory Democracy Revisited.” Perspectives on Politics 10 (01): 7-19.

732 doi:10.1017/S1537592711004877.

733 Porto de Oliveira, Osmany. 2017. International Policy Diffusion and Participatory Budgeting. Palgrave Macmillan.

734 doi:10.17141/mundosplurales.2.2018.3496.

735 Rodden, Jonathan. 2005. "Hamilton's Paradox:"

736 Russon Gilman, Hollie. 2016. Democracy Reinvented. Participatory Bud Geting and Civic Innovation in America.

737 Washington, D.C.: Brookings Institution Press.

738 Senplades. 2009. Plan Nacional Para El Buen Vivir 2009-2013: Construyendo Un Estado Plurinacional e

\section{Intercultural.}

740

Senplades. 2010. Lineamientos Para La Planificación Del Desarollo y El Ordenamiento Territorial. Quito:

741 Secretaria Nacional de Planificación y Desarollo.

742 Senplades. 2013. "Ecuador Plan Nacional Del Buen Vivir 2013-2017.” Quito: Secretaria Nacional de Planificación y 743 Desarollo.

744 Senplades. 2014. Proceso de Formulación y/o Actualización de Planes de Desarrollo y Ordenamiento Territorial.

745 Quito: Secretaria Nacional de Planificación y Desarollo.

746 Senplades. 2016. Lineamientos de Seguimiento y Evaluación a Los Planes de Desarrollo y Ordenamiento Territorial.

747 Quito: Secretaria Nacional de Planificación y Desarollo.

748 Sintomer, Yves, Giovanni Allegretti, and Carsten Herzberg. 2010. "Learning from the South: Participatory Budgeting Worldwide," no. 25.

751

752

753

754

755

756

757

758

759

760

761

762

763

764

765

766

767

768

769

Sintomer, Yves, Anja Röcke, and Carsten Herzberg. 2016. Participatory Budgeting in Europe: Democracy and Public Governance. Routledge.

Souza, Celina. 2001. "Participatory Budgeting in Brazilian Cities: Limits and Possibilities in Building Democratic Institutions." Environment and Urbanization 13 (1): 159-184. doi:10.1177/095624780101300112.

Theesfeld, Insa, Tom Dufhues, and Gertrud Buchenrieder. 2017. “The Effects of Rules on Local Political DecisionMaking Processes: How Can Rules Facilitate Participation?” Policy Sciences 50 (4): 675-696. doi:10.1007/s11077-017-9284-2.

Tiebout, Charles M. 1956. “A Pure Theory of Local Expenditures.” Journal of Political Economy, 64 (5): $416-424$.

Touchton, Michael, and Brian Wampler. 2013. "Improving Social Well-Being Through New Democratic Institutions." Comparative Political Studies 47 (10): 0010414013512601. doi:10.1177/0010414013512601.

UN-Habitat. 2009. Presupuestos Participativos En El Ecuador - Análisis Del Camino Recorrido Para Definir Pasos Futuros. Quito: UN-HABITAT.

Wampler, Brian. 2004. “Expanding Accountability through Participatory Institutions: Mayors, Citizens, and Budgeting in Three Brazilian Municipalities.” Latin American Politics and Society 46 (2). Lynne Rienner Publishers: 73-99. doi:10.1111/j.1548-2456.2004.tb00276.x.

Weingast, Barry R. 2014. "Second Generation Fiscal Federalism: Political Aspects of Decentralization and Economic Development.” World Development 53. Elsevier Ltd: 14-25. doi:10.1016/j.worlddev.2013.01.003.

Wright, Glenn Daniel, Krister Andersson, Clark Gibson, and Tom Evans. 2015. "What Incentivizes Local Forest Conservation Efforts? Evidence from Bolivia.” International Journal of the Commons 9 (1): 322-346. doi:10.18352/ijc.494. 